\title{
Diet and trophic ecomorphology of the silverside, Odontesthes bonariensis, of the Salto Caxias reservoir, rio Iguaçu, Paraná, Brazil
}

\author{
Fernanda Aparecida da Silva Cassemiro*, Norma Segatti Hahn* \\ and Thiago Fernando Lopes Valle de Britto Rangel**
}

This study aims to analyze the diet and trophic ecomorphology of Odontesthes bonariensis, relating these features with species' abundance in the natural environment and in the Salto Caxias reservoir (at Iguaçu river) after the reservoir's formation. The samples were carried out before (from March 1997 to February 1998- pre) and after (from October 1998 to February 2001 post 1 and 2) the damming. The stomach contents of 218 individuals were analyzed by occurrence and volumetric methods. $O$. bonariensis' diet is based on insects, scales, plants and detritus. Microcrustaceans (Cladocera and Copepoda) were the main items, allowing the characterization of the species as zooplanktivore. The species has a superior position and protractible mouth, with small teeth, creating a serrated pattern, uniformly lined side by side. There are many gill rakers, that are long and close together (typical of filtering fishes); the stomach is ill defined and the intestine is short. There was a gradual increase of $O$. bonariensis' abundance during the period of field study, mainly after the second year of damming. This fact seems to be closely related with the high abundance and availability of zooplankton in the dammed environment, and also with the ability of the species to exploit this resource.

Este estudo teve como objetivo analisar a dieta e ecomorfologia trófica de Odontesthes bonariensis, relacionando estes aspectos à abundância da espécie, no ambiente natural e após a formação do reservatório de Salto Caxias, Rio Iguaçu. As coletas foram realizadas antes (de março de 1997 a fevereiro de 1998 - pré-represamento) e após o represamento (de outubro de 1998 a fevereiro de 2001- pós 1 e 2) e os conteúdos estomacais de 218 exemplares foram analisados pelos métodos de ocorrência e volumétrico. A dieta baseou-se em insetos, escamas, vegetais e detritos, sendo que microcrustáceos (Cladocera e Copepoda) foram dominantes, permitindo caracterizar a espécie como zooplanctívora. A espécie possui boca superior e protátil com dentes pequenos, dispostos em fileiras, conferindo-lhes um aspecto serrilhado. Os rastros branquiais são numerosos, longos e próximos entre si (típico de peixe filtrador), o estômago é pouco definido e seu intestino curto. Houve um incremento gradativo na abundância de $O$. bonariensis, durante o período de coletas, principalmente no segundo ano após o represamento. Este fato parece estar estreitamente relacionado com a elevada abundância e disponibilidade de zooplâncton no ambiente represado e a capacidade da espécie em explorar este recurso.

Key words: Atherinidae, feeding, planktivory, morphology, freshwater.

\section{Introduction}

The construction of Salto Caxias UHE, in October 1998, has created the fifth and last reservoir of a rank of four other reservoirs upstream of the rio Iguaçu (Júlio Júnior et al., 1997). Studies about the fish fauna began one year before dam closure and extended two years more (Project-UEM/Nupélia/COPEL).

These studies estimated that fish fauna in this envi- ronment compose almost $80 \%$ of the endemic species, and Odontesthes bonariensis is one of the eight introduced species, although its introduction to the rio Iguaçu is not well documented. It is an indigenous species of the Argentine and South extreme Brazil (Bemvenuti, 1990), and it has been introduced in some reservoirs (Quirós \& Boveri, 1999) due to its good adaptation to lentic ecosystems with medium and high productivity. Moreover, it represents high fishing

\footnotetext{
* Núcleo de Pesquisas em Limnologia, Ictiologia e Aquicultura (Nupélia), Universidade Estadual de Maringá, Av. Colombo 5790. 87020-900 Maringá, Paraná, Brazil. e-mail: hahnns@ nupelia.uem.br

** Laboratório de Ecologia Teórica e Síntese, DBG, ICB, Universidade Federal de Goiás
} 
resource for sports and commercial fishing (Scasso \& Campos, 1999). Bemvenuti (2002) points out that other Atherinidae species are also used in also used in aquiculture and so, suggests more detailed biological studies about this taxonomic group.of $O$. bonariensis.

In recently formed reservoirs, many species, at least temporarily, change their food habits, except those that have strong morphologic adaptations (such as specialist species) or those whose preferential food resources increase or remain constant. Studies in Salto Caxias reservoir, before and after impoundment, estimated that at least $30 \%$ of the species changed its diets (Delariva, 2002).

The few studies about natural feeding of $O$. bonariensis report its omnivory feeding habit (Ringuelet, 1942) or its zooplanktivory facultative habit (Ringuelet, 1967). Ontogenetic shift diet was reported by Piedras et al., (1987) and Bemvenuti (1990), which showed that juvenile specimens eat zooplankton and adult specimens are insectivores or piscivores.

In this study, we analyzed some of the $O$. bonariensis' biological features, such as natural feeding, trophic morphology and abundance during the formation of Salto Caxias reservoir. In order to establish their feeding habit in the recently created environment, we take into account the relationship between diet and trophic morphology. We also discuss if these factors had been influenced by the abundance of the species at this reservoir.

Study Area. The studied area is located in the influence area of Salto Caxias reservoir ( $25^{\circ} 32^{\prime} \mathrm{S}$ and $53^{\circ} 30^{\prime} \mathrm{W} ; 25^{\circ} 35^{\prime} \mathrm{S}$ and $53^{\circ} 06^{\prime} \mathrm{W}$ ), at the Iguaçu river, Southwest of the Paraná state, between municipal districts of Capitão Leônidas Marques and Nova Prata do Iguaçu. This reservoir is located about $180 \mathrm{~km}$ upstream of the Iguaçu waterfalls and $100 \mathrm{~km}$ downstream of the Salto Osório reservoir (Fig.1).

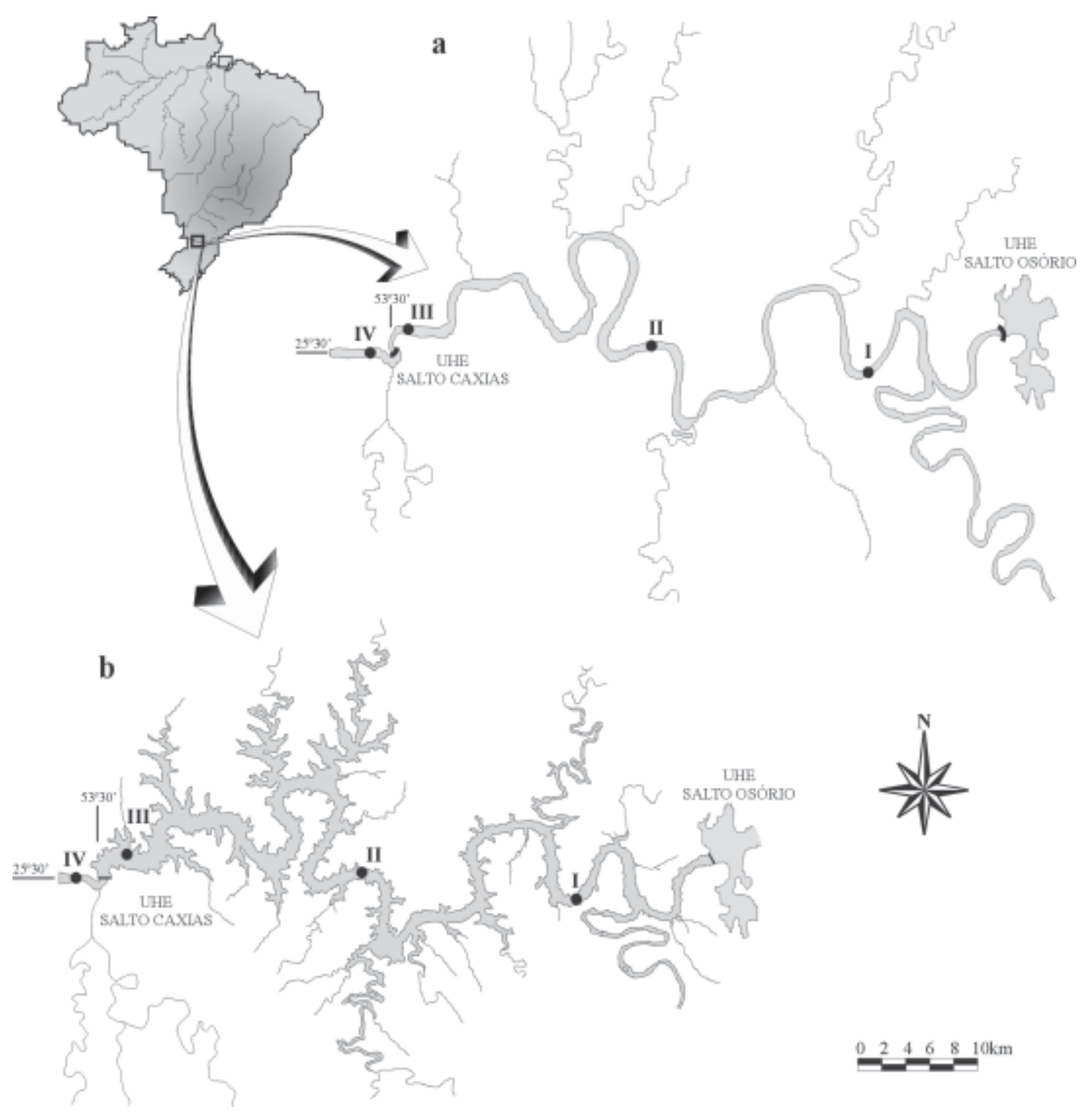

Fig. 1. Map of the studied area. Iguaçu river (a) and Salto Caxias reservoir (b). 


\section{Material and Methods}

Different sampling sites were chosen along the reservoir, distributed in: I- downstream of the UHE Salto Osório; IIPorto Vorá; III- upstream of the dam; IV- downstream of the UHE Salto Caxias. Eleven more sites located in small rivers near the dam were sampled (Fig. 1).

Samples were taken using three batteries of 15 gillnets $(2.4$ to $14.0 \mathrm{~cm})$ left for 24 hours. Fish were removed in the morning (8:00h), evening (16:00h) and at night (22:00h). In the pre-impoundment period the samples were taken from March 1997 to February 1998 (in order to calculate the species' abundance) and the post-impoundment period, from November 1998 to January 2000 (post 1) and March 2000 to February 2001 (post 2).

The specimens captured were measured and weighed. The digestive tract was excised and fixed in $4 \%$ formaldehyde. The stomach contents of 218 specimens, with standard length varying from $6.0 \mathrm{~cm}$ to $27.0 \mathrm{~cm}$ (mean $=17.3 \mathrm{~cm})$, including juvenile and adult specimens, were analyzed by frequency of occurrence and volumetric methods. Volume of each food item was determined using graduated test tubes and a counting chamber for items whose volume was lower than $0.1 \mathrm{ml}$ (Hellawel \& Abel, 1971).

Dates of stomach content analysis were graphically represented according to Costello (1990). The method consists of scatter plot of volume values in the $y$ axis and occurrence values in the $\mathrm{x}$ axis. Points located near $100 \%$ of occurrence and $1 \%$ of volume show that the predator consumed different preys in low quantity, a hypothetical example of a trophic generalist species; on the other hand, points located near $1 \%$ of occurrence and $100 \%$ of volume show that the predator is a specialist for a given prey.

Voucher specimens are deposited at the ichthyological collection of the Center of Research in Limnology, Ichtyology and Aquiculture (Nupélia): NUP 1610 (06 ex.), Salto Caxias reservoir, Iguaçu river basin, Paraná state, Brazil, 2001, collected by Nupélia staff. Ten specimens of different sizes were taken at random for morphologic characterization. We drew and described the position and shape of mouth, gill rakers and digestive tract.

The species' abundance was estimated in terms of number of captures by unit of effort (CPUE). This measure is given by the number of specimens by $1000 \mathrm{~m} 2$ of net in 24 hours and taken by formula: $\mathrm{CPUE}=(C / E) \times 1000 \mathrm{~m} 2 / 24$ hours, where: $\mathrm{CPUE}=$ Number of specimens by $1000 \mathrm{~m} 2$ of net $/ 24$ hours; $C=$ Number captured specimens; $E=$ Total of effort (as m2 of net).

\section{Results}

Diet. The diet ranged among microcrustaceans, insects, scales, plants and detritus. However, Copepoda and Cladocera were the most important items, representing $82 \%$ of occurrence and $49 \%$ of the total volume and Cladocera $48 \%$ of occurrence and $15 \%$ of the total volume. The other items were all rare (Fig. 2).

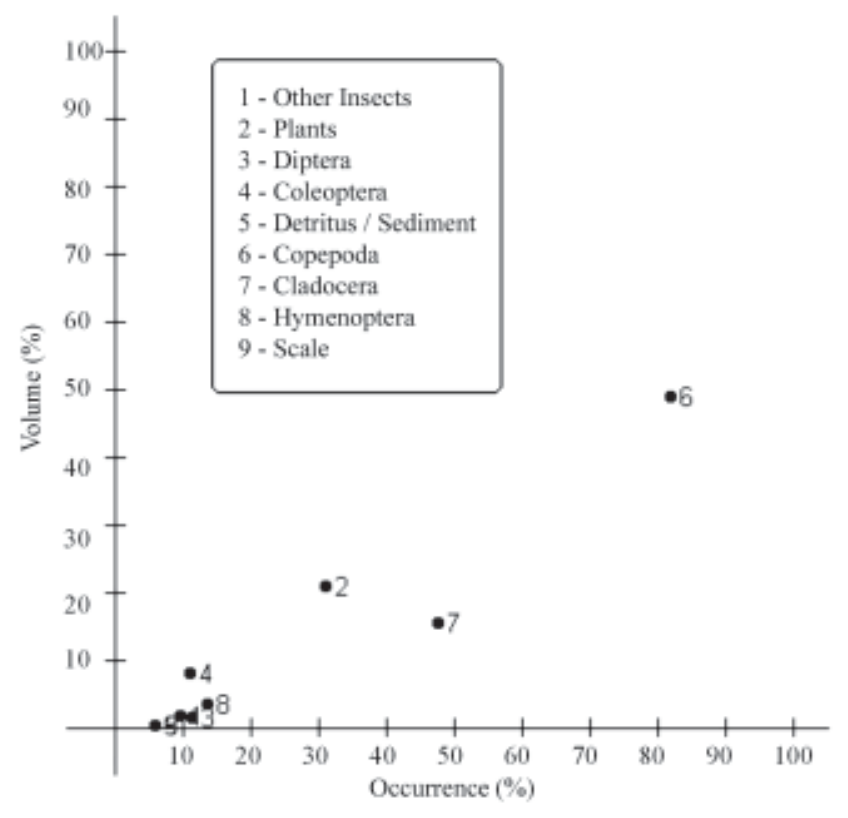

Fig. 2. Proportion of the food items in the diet of the $O$. bonariensis representing by Costello's method.

Trophic morphology. The mouth of this species shows superior position with reduced lips. The premaxillary is separated from the maxillary bone by thick and strong skin permitting wide protractibility to this organ. The teeth are small, similar among themselves and with uniform distribution. There are three at four ranks of teeth in premaxillary and dentary bones, creating a serrated pattern (Fig. 3 a). The gill rakers (just at the first arch), numerous and comb-shaped prolonged structures, are close together (Fig. $3 \mathrm{~b}$ ). The first portion of the digestive tract is a short esophagus. It is followed by a straight and ill defined stomach whose wall is thick, and continues to a short intestine (Fig. $3 \mathrm{c}$ ).

Capture. Dates of captures of $O$. bonariensis before and after damming showed considerable increase in abundance, mainly in the second year (post 2) after damming (Fig. 4).

\section{Discussion}

Odontesthes bonariensis had a zooplanktivore feeding habit at Salto Caxias reservoir (independently of the individuals class sizes), in partial agreement with other studies about this species in natural environments (Ringuelet, 1942; Hartz, 1997; Bemvenuti, 1990; 2002). Besides of the tendency in exploit zooplankton organisms, the dammed environment had certainly favored this strategy by the wide availability of this food supply. It's well known that the first years of damming are characterized by the high rates of primary productivity, which increase the biological productivity in other levels of the food web, such as the zooplankton organisms. It is generally attributed to the high levels of nutrients availability within impounded environments, a consequence of the organic matter that had been flooded (O'Brien, 1990). 
Studies about the zooplankton communities carried out before and after the Salto Caxias damming showed a significant increase of these organisms in the environment (Serafim Júnior, 2002). Although some fish species fed on microcrustaceans, mainly during the second year of reservoir formation (pers. obs.), to $O$. bonariensis this was an almost exclusive food supply.
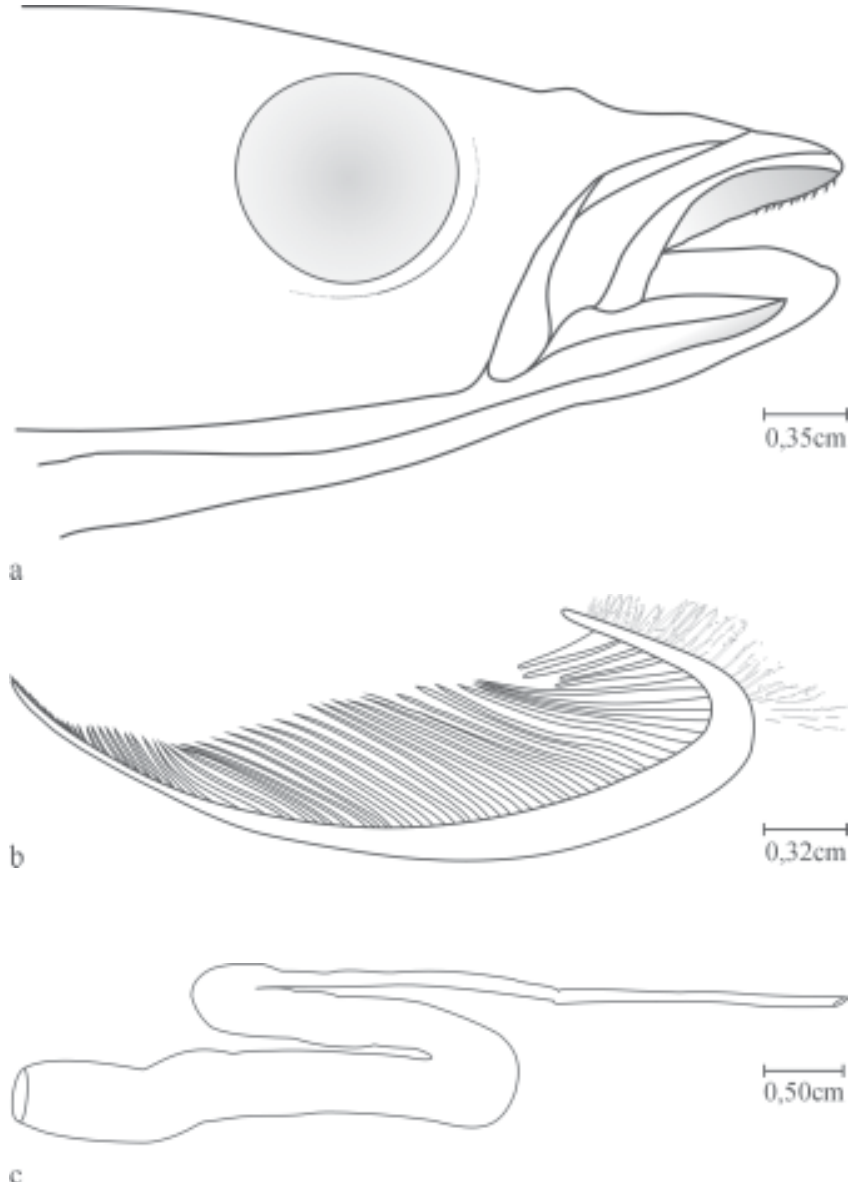

Fig. 3. a) Position and form of the mouth of $O$. bonariensis; b) left gill rackers; c) digestive tract.

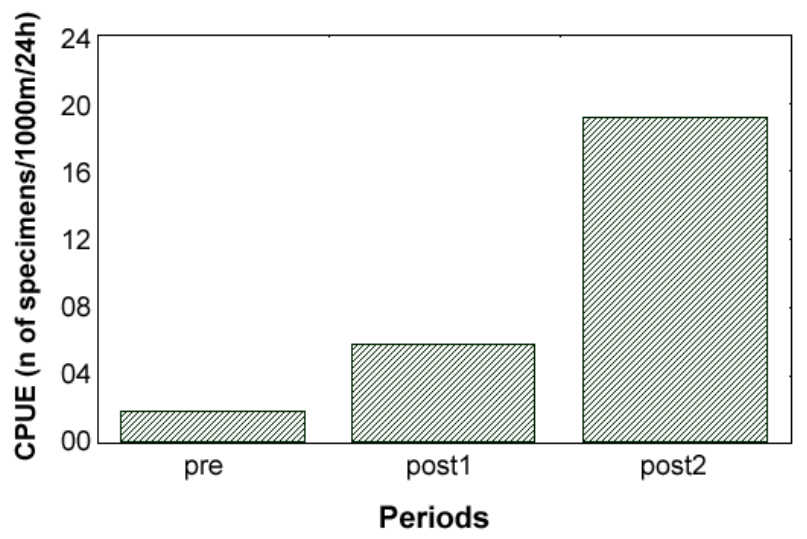

Fig. 4. Odontesthes bonariensis numerical abundance (CPUE), before and after the Salto Caxias damming.
Morphological patterns related to feeding markedly reflect the diet of a fish, mainly when it is a specialist species. The position and morphology of the mouth can indicate the depth in the water column where the fish is feeding; the gill rakers specify the size of the prey, while the form and length of the intestine point to the resource type.

Bemvenuti (1990), studying morphological patterns of two species of silverside, pointed out that to Odontesthes sp., as the mouth diameter increase, the individuals change the feeding habit from "sucker" to "grabber". Probably, this strategy could be similar to $O$. bonariensis'. However, in lentic environments, with a wide range of availability of microcrustaceans, it is possible that $O$. bonariensis could use both ways to capture their preys. The mouth and the big eye suggest that it is a particulate-feeder, making use of visual cues to seek and capture its prey (Gerking, 1994), whereas the patterns of gill rakers (similar to Hypophthalmus edentatus, a typical filtering fish from Paraná river) suggest feeding by filtration.

Some authors point out the ill defined morphology of $O$. bonariensis' digestive tract (De Buen, 1953, Bemvenuti, 1990; 2002), although Boschi \& Fuster de Plaza (1959) think that this pattern is common among omnivores fish species. Conversely, the majority of fishes typically omnivores, such as Pimelodus maculatus, have this morphological patterns very conspicuous (Lolis \& Andrian, 1996). These authors defined the stomach of Pimelodus maculatus as sack shaped, and according to them it is typical of omnivores and generalist carnivores. Again it is convenient to trace back to $H$. edentatus, whose digestive tract is very similar to $O$. bonariensis' (pers. obs.); this comparison could mean that a little-defined digestive tract it typical of zooplanktivore, rather than omnivore fishes.

An unavoidable effect of impoundment on the aquatic fauna is a shift in species composition and abundance, with extreme proliferation of some species and reduction, or even local extinction, of others (Agostinho et al., 1999). Many factors could influence fish colonization at the dammed environments, but food supply is one of the most important ones. Some fishes respond quickly to impoundment, whereas others respond only after years or decades, according to their trophic nature (Agostinho et al., op. cit.).

The shift in the population size (i.e. number of individuals) after the damming was well-marked during the samples, and this could indicate that, in spite of an initial stabilization process, the species had found favorable conditions for the adaptation in the lentic environments. Although this increment had been real for the silverside during the studied period, an increase of fishing effort in the second year after the damming; might had been responsible for the largest contribution of the species in that time. However, we attributed the increase of the population size as a function of the large abundance of its preferred food resource and its capacity (morphological adaptation) to exploit this available food supply. We also highlight that this species is already reproducing in the dammed environment.

Similar facts were observed in the Itaipu reservoir regarding H. edentatus, whose capture was rare before damming, and 
became one of the species more exploited in the commercial fishing after the damming (Agostinho et al., 1994).

We conclude that the above mentioned patterns about the diet were closely related with the population size of $O$. bonariensis after the damming. Although in that time it had presented a restricted diet, as a function of the high abundance of zooplankton, other authors pointed out the $O$. bonariensis ability to exploit another resource in the environment such as insects, mollusks, crustaceans, other invertebrates and fishes. Hence, it could be expected that as the food supply decreases, $O$. bonariensis changes, at least partially, its diet, not necessarily reducing the population size, since it is known that it could also change feeding habits according to the availability of each food resource.

\section{Acknowledgements}

Our research programs on trophic ecology and ecomorphology have been continuously supported by Nupélia/UEM, Companhia de Energia Elétrica do Paraná (COPEL) and Conselho Nacional de Desenvolvimento Científico e Tecnológico $(\mathrm{CNPq})$ in terms of field study financial support and personal grants (CNPq procs. 350538/02-6 to NSH, 370922/ 02-6 to FASC and 101379/02 to TFLVBR). We are also grateful to Eric Dibble (Mississipi State University) for reviewing the English manuscript.

\section{Literature Cited}

Agostinho, A. A., E. Benedito-Cecílio, L. C. Gomes \& A. A. Sampaio. 1994. Spatial and temporal distribution of sardela, Hypophthalmus edentatus (Pisces, Siluroidei), in the area of influence the Itaipu reservoir (Paraná, Brazil). Revista Unimar, 3: 27-40.

Agostinho, A. A., L. E. Miranda, L. M. Bini, L. C. Gomes, S. M. Thomaz \& H. I. Suzuki. 1999. Patterns of Colonization in Neotropical Reservoirs, and Prognoses on Aging. In: J. G. Tundisi \& M. Straskraba (Eds). Theoretical Reservoir Ecology and its Applications. São Carlos, International Institute of Ecology. 585p.

Bemvenuti, M. A. 1990. Hábitos alimentares de peixes-rei na região estuarina da Lagoa dos Patos, RS, Brasil. Atlântica, 12: 79-102.

Bemvenuti, M. A. 2002. Diferenciação morfológica das espécies de peixes-rei, Odontesthes Evermann \& Kendall (Osteichthyes, Atherinopsidae) no extremo sul do Brasil: morfometria multivariada. Revista Brasileira de Zoologia, 1: 251-287.

Boschi, E. E. \& M. L. Fuster de Plaza. 1959. Estudio biológico pesquero del pejerrey del embalse del Rio III (Basilichthys bonariensis), con una contribuición al conocimento limnologico del ambiente. Departamento de Invetigaciones Pesqueras, Secretaria de Agricutura y Ganadeira, Public. Buenos Aires, 8:3-16.

Costello, M. J. 1990. Predator feeding strategy and prey importance: a new graphical analysis. Journal of Fish Biology, 36:261-263.
De Buen, F. 1953. Los pejerreyes (Familia Atherinidae) en la fauna Uruguaya, con descripción de nuevas especies. Boletim do Instituto Oceanográfico de São Paulo, 4: 3-80.

Delariva, R. L. 2002. Ecologia trófica da ictiofauna do rio Iguaçu, PR e efeitos decorrentes do represamento de Salto Caxias. Unpublished Ph.D. Dissertation. Universidade Estadual de Maringá, Maringá. 65p.

Gerking, S. D. 1994. Feeding ecology of fish. New York, Academic Press. 416p.

Hartz, S. M. 1997. Alimentação e estrutura da comunidade de peixes da Lagoa Caconde, litoral norte do Rio Grande do Sul, Brasil. Unpublished Ph. D. Dissertation. Universidade Federal de São Carlos, São Carlos. 282p.

Hellawell, J. \& R. Abel. 1971. A rapid volumetric method for the analysis of the food of fishes. Journal of Fish Biology, 3: 29-37.

Júlio Júnior, H. F., C. C. Bonecker \& A. A. Agostinho. 1997. Reservatório de Segredo e sua inserção na bacia do rio Iguaçu. In: Agostinho, A. A. \& L. C. Gomes. (Eds.). Reservatório de Segredo: bases ecológicas para o manejo. Maringá. Eduem: 1-17.

Lolis, A. A. \& I. F. Andrian. 1996. Alimentação de Pimelodus maculatus Lacépede, 1803 (Siluriformes, Pimelodidae), na planície de inundação do Alto Rio Paraná, Brasil. Boletim do Instituto de Pesca, 23: 187-202.

O’brien, W. J. 1990. Perspectives on Fish in Reservoir Limnology. In: Thorton, W. K. (Ed.). Reservoir Limnology: Ecology Perspectives. New York: 209-225.

Piedras, S. R., P. R. R. Moraes, J. E. C. Oliveira, M. B. De Leon \& A. C. M. Oliveira. 1987. Observações preliminares sobre o povoamento de açudes na zona sul no Rio Grande do Sul, com peixe-rei de água doce. Caderno UCPel. : 6-19.

Quirós, R. \& M. B. Boveri. 1999. Fish Effects on Reservoir Trophic Relationships. In: Tundisi, J. G. \& M. Straskraba (Eds.). Theoretical Reservoir Ecology and its Applications. São Carlos, International Institute of Ecology. 585p.

Ringuelet, R. A. 1942. Ecología alimentícia del pejerrey Odontesthes bonariensis com notas limnologicas sobre la Laguna Chascomús. Revista del Museu de la Plata, 2: 427-461.

Ringuelet, R. A., R. H. Aramburu \& A. A. de Aramburu. 1967. Los peces argentinos de água Dulce. Comisión de Investigación Científica (Gobernación) Provincia de Buenos Aires. La Plata, Dirección de Impresiones del Estado y Boletín Oficial. 600p.

Scasso, F. \& H. Campos. 1999. Comparison of two populations of silverside (Odontesthes bonariensis) in eutrophic lakes of central Chile. Journal of Freshwater Ecology, 1: 61-70.

Serafim Júnior, M. 2002. Efeitos do represamento em um trecho do médio rio Iguaçu sobre a estrutura e dinâmica da comunidade zooplanctônica. Unpublished Ph. D. Dissertation. Universidade Estadual de Maringá, Maringá. $51 \mathrm{p}$.

Received August 15, 2003 Accepted November 23, 2003 